\title{
Pendidikan Gizi Gemar Makan Ikan Sebagai Upaya Peningkatan Pengetahuan Ibu tentang Pencegahan Stunting Di Desa Gempolmanis Kecamatan Sambeng Kabupaten Lamongan Provinsi Jawa Timur
}

\author{
Nutrition Education "Gemar Makan Ikan" to Increase Mother's Knowledge of \\ Stunting Prevention in Gempolmanis Village, Sambeng District, Lamongan \\ Regency, East Java Province
}

Qonita Rachmah ${ }^{1 *}$, Diah Indriani², Susi Hidayah ${ }^{1}$, Yurike Adhela ${ }^{1}$, Trias Mahmudiono ${ }^{1}$

ABSTRAK

Latar belakang : Stunting merupakan salah satu permasalahan gizi dengan dampak kesehatan yang serius. Hasil riskesdas terbaru di tahun 2018 menunjukkan prevalensi stunting sebesar 30,8\%, yang artinya 1 dari 3 anak indonesia masih mengalami stunting. Kabupaten Lamongan merupakan satu dari 100 kabupaten prioritas stunting di Indonesia.

Tujuan : Tujuan dari penelitian ini adalah untuk menganalisis pengaruh pemberian pendidikan gizi terhadap pengetahuan ibu tentang Pencegahan Stunting.

Metode : Metode yang digunakan dalam penelitian ini adalah Quasi Eksperimen dengan rancangan one group pre-test and post-test design. Teknik pengambilan sampel menggunakan metode total sampling yaitu mengambil semua ibu dengan balita usia 0 - 59 bulan di desa Gempolmanis, Kecamatan Sambeng, Kabupaten Lamongan sebanyak 22 ibu balita. Pemilihan desa Gempolmanis dipilih secara purposive. Uji T dependen digunakan untuk mengukur perbedaan tingkat pengetahuan ibu setelah diberikan pendidikan gizi. Response rate penelitian ini sebesar $86,4 \%$.

Hasil : Hasil penelitian menunjukkan pada awal sesi sebelum diberikan pendidikan gizi tentang stunting, mayoritas ibu masih memiliki pengetahuan yang cukup (57,9\%) dan kurang (36,8\%). Hanya 5,3\% yang memiliki pengetahuan gizi baik, namun setelah edukasi gizi, $68,4 \%$ ibu memiliki tingkat pengetahuan baik. Rerata skor sebelum edukasi sebesar $60,5 \pm 18,9$ dan meningkat menjadi $88,4 \pm 13,8$ setelah edukasi gizi $(P<0.05)$.

Kesimpulan : Dapat disimpulkan bahwa pendidikan gizi secara signifikan dapat meningkatkan pengetahuan ibu terkait pencegahan stunting pada anak di usia golden period. Pemberian edukasi gizi secara berkala baik oleh petugas gizi puskesmas maupun kader posyandu perlu dilakukan sebagai upaya pencegahan stunting.

Kata kunci: konsumsi ikan, pendidikan gizi, penyuluhan, stunting

\section{ABSTRACT}

Background: Stunting is one of nutritional problem that causes long-term health problems. Based on the result of Riskesdas, there has been an increase in stunting prevalence from 35,6\% in 2010 to 37,2\% in 2013 which means that 1 in 3 indonesian children are stunting. Lamongan was one of hundred's stunting priority regency in Indonesia. This study aims to analyze the effect of nutrition education to incerase mother's knowledge related stunting.

Objective: The method used in this research is Quasi Experiment by designing one group pre-test and post-test design. The sampling technique used was total sampling method in which all mothers with children aged 0 - 59 months in Gempolmanis village, Sambeng District, Lamongan Regency. The Gempolmanis village was purposively chosen.

Methods: The dependent $T$ test was used to determine the effect of nutrition education on maternal knowledge. The response rate of this study was $86.4 \%$.

Results: The results showed at the beginning of the session, the majority of mothers still had sufficient knowledge (57.9\%) and less (36.8\%). Only 5.3\% have good nutrition knowledge, but after nutrition education, $68.4 \%$ of mothers have a good level of knowledge related to stunting. The mean score before nutrition education was $60.5 \pm 18.9$ and increased to $88.4 \pm$ 13.8 after nutrition education $(p<0.05)$.

Conclusion: It can be concluded that nutrition education can significantly increase maternal knowledge related to the prevention of stunting in children at the golden age. Regular nutrition education by the nutrition officer or posyandu cadre needs to be done as an effort to improve stunting.

Keywords: fish consumption, nutrition education, counseling, stunting 


\author{
*koresponden: \\ Qonita Rachmah \\ qonita.rachmah@fkm.unair.ac.id \\ ${ }^{1}$ Departemen Gizi Kesehatan, Fakultas Kesehatan Masyarakat, Universitas Airlangga, Indonesia \\ ${ }^{2}$ Departemen Biostatistika dan Kependudukan, Fakultas Kesehatan Masyarakat, Universitas Airlangga, Indonesia
}

\section{PENDAHULUAN}

Stunting merupakan salah satu permasalahan gizi terbanyak yang terjadi di dunia dan di Indonesia $(1,2)$. Definisi stunting menurut Kementerian Kesehatan (Kemenkes) adalah anak balita dengan nilai z-scorenya kurang dari -2SD/ (stunted) dan kurang dari - 3SD (severely stunted) dengan panjang badan ( $\mathrm{PB} / \mathrm{U}$ ) atau tinggi badan (TB/U) menurut umurnya dibandingkan dengan standar baku WHO-MGRS (Multicentre Growth Reference Study) 2006 (3). Masalah anak stunting dapat menghambat perkembangan anak, dengan dampak negatif yang akan berlangsung pada kehidupan selanjutnya, berhubungan dengan prestasi pendidikan yang buruk dan pendapatan yang rendah saat dewasa, sehingga menghadapi kemungkinan yang lebih besar untuk tumbuh menjadi orang dewasa yang kurang berpendidikan, miskin, kurang sehat dan lebih rentan terhadap penyakit tidak menular (1). Hasil Riskedas tahun 2013 menunjukkan bahwa telah terjadi peningkatan prevalensi stunting dari 35,6\% tahun 2010 menjadi 37,2\% tahun 2013, artinya 1 dari 3 anak Indonesia tergolong stunting. Jawa Timur merupakan salah satu provinsi yang memiliki prevalensi stunting tinggi (4). Berdasarkan data Tim Nasional Percepatan Penanggulangan Kemiskinan (TNP2K), Desa Gempol Manis Kecamatan Sambeng Kabupaten Lamongan Provinsi Jawa Timur merupakan salah satu dari 100 Kabupaten/Kota Prioritas untuk intervensi stunting/anak kerdil di Indonesia (5).

Kondisi stunting disebabkan karena kurangnya asupan energi dan protein dalam jangka waktu panjang, dimulai dari masa kehamilan. Oleh karena itu, pendidikan gizi terpadu terkait stunting dan KEP serta pemberdayaan masyarakat untuk menanggulangi stunting dan KEP perlu dilakukan. Asupan protein yang cukup selama golden period (bayi hingga usia 2 tahun) menajadi hal yang penting dalam pencegahan stunting. Studi di Kabupaten Bangkalan, Madura menunjukkan bahwa balita dengan asupan protein inadekuat memiliki risiko yang lebih tinggi untuk mengalamin stunting dibandingkan dengan balita dengan asupan protein adekuat dari Angka Kecukupan Gizi (AKG) yang dianjurkan (6). Salah satu sumber protein yang banyak tersedia dengan harga cukup terjangkau yaitu ikan. Penelitian di Rowosari, Semarang menunjukkan bahwa konsumsi ikan secara signifikan berkorelasi dengan kejadian stunting (24).

Ikan merupakan salah satu jenis protein heme yang memiliki tingkat penyerapan besi yang baik. Kandungan protein dalam ikan mencapai $18 \%$ dan terdiri dari asam amino esensial. Menurut Daftar Bahan Makanan Penukar (DBMP) Indonesia, satu porsi ikan segar (50 g) mengandung 10 gram protein (7/3). Studi Diet Total pada 2014 melaporkan rata-rata konsumsi kelompok ikan dan olahannya. Pada kelompok anak usia $5-12$ tahun adalah sebesar 70,7 gram per orang per hari, dengan persentase paling banyak berasal dari ikan laut sebanyak 37,9 gram per orang per hari atau setara dengan 54\% dari total konsumsi ikan dan dilanjutkan oleh kelompok ikan tawar yang menyumbang $38 \%$ dari total konsumsi ikan atau sekitar 26,9 gram per orang per hari (8/4). Laporan tahunan Kementerian Kelautan dan Perikanan menunjukkan bahwa konsumsi ikan per kapita per tahun mengalami peningkatan sejak 2010 hingga 2014. Pada 2010, konsumsi ikan masih sebesar 30,48 $\mathrm{kg} / \mathrm{kapita} /$ tahun dan terus meningkat hingga 38,14 $\mathrm{kg} / \mathrm{kap} /$ tahun pada 2014 dengan pertumbuhan tertinggi mencapai 8,32\% per tahun. Jawa Timur merupakan salah satu provinsi dengan pertumbuhan konsumsi ikan per $\mathrm{kg} / \mathrm{kapita} /$ tahun paling tinggi sejak tahun 2010 - 2014 . Konsumsi ikan per 2010 hanya terhitung 19,01 $\mathrm{kg} / \mathrm{kap} /$ tahun hingga $27,89 \mathrm{~kg} / \mathrm{kap} /$ tahun dengan pertumbuhan sebesar $46 \%$ dalam 4 tahun terakhir. Konsumsi ikan di Jawa Timur diprediksi akan terus naik (9/5). Pada tahun 2019, konsumsi ikan ditargetkan mencapai $54.49 \mathrm{~kg} / \mathrm{kap} / \operatorname{tahun}$ (10/6). Paparan Kementerian Kesehatan menunjukkan bahwa tingkat pendidikan orang tua merupakan salah satu determinan utama dari terjadinya masalah stunting. Oleh karena itu, pendidikan gizi dapat menjadi salah satu solusi pencegahan stunting (23).

Solusi permasalahan yang telah dipaparkan diatas salah satunya dapat dilakukan melalui pendidikan gizi gemar makan ikan. Ikan merupakan sumber protein yang dapat dengan mudah diperoleh namun konsumsinya masih cukup rendah di kalangan masyarakat. Penelitian ini bertujuan untuk menganalisis pengaruh pemberian pendidikan gizi terhadap pengetahuan ibu tentang Pencegahan Stunting Di Desa Gempolmanis Kecamatan Sambeng Kabupaten Lamongan Provinsi Jawa Timur

\section{METODE}

Penelitian ini merupakan penelitian Quasi Eksperimen dengan rancangan one group pre-test and post-test design. Penelitian ini dilaksanakan di Posyandu Desa Gempolmanis, Kecamatan Sambeng, Lamongan Jawa Timur. Pemilihan lokasi peneitian dipilih secara purposive berdasarkan data yang menunjukkan bahwa prevalensi stunting di Desa Gempolmanis termasuk dalam peringkat 100 besar (5). Populasi dalam penelitian ini adalah seluruh ibu yang memiliki anak berusia $0-59$ bulan sebanyak 22 orang, dengan sampel juga sebanyak 22 orang yang dipilih berdasarkan total sampling. Intervensi yang dilakukan berupa edukasi gizi dengan metode ceramah dan tanya jawab.

Pengumpulan data dilakukan dengan kuesioner self-assessment dengan asistensi dari enumerator sebanyak 2 (dua) orang Sarjana Gizi. Kuesioner pengetahuan tentang pencegahan stunting berisi sepuluh pertanyaan pilihan ganda. Kuesioner diisi sebanyak dua kali yaitu sebelum dan sesudah diberikan intervensi pendidikan gizi. Intervensi yang diberikan berupa ceramah terkait stunting, MPASI, pemilihan makanan 
bergizi dan pemilihan ikan, lalu dilanjutkan dengan sesi interaktif tanya jawab. Intervensi berlangsung selama 60 menit. Pengolahan data dilakukan dengan SPSS 22 IBM Statistics dengan analisis statistik Uji T dependen $(\alpha<0,05)$ untuk melihat adanya peningkatan pengetahuan. Dari 50 peserta, hanya 19 responden yang mengisi kuesioner secara lengkap sehingga analisis data hanya dilakukan pada 19 responden.

\section{HASIL DAN PEMBAHASAN}

Desa Gempol Manis terletak di Kecamatan Sambeng, Kabupaten Lamongan, Provinsi Jawa Timur, Indonesia. Desa ini terletak di sebelah selatan, sekitar 35 kilometer dari ibu kota Kabupaten Lamongan. Secara geografi, sebelah utara merupakan Kecamatan Sugio, sebelah Selatan yakni Kecamatan Kabuh dan Kecamatan Kudu yang termasuk Kabupaten Jombang, sebelah barat yakni Kecamatan Ngimbang dan yang terakhir sebelah timur yakni Kecamatan Mantup. Desa Gempol Manis terdiri dari 5 dusun dan memiliki 1 posyandu umum. Berdasarkan hasil observasi, posyandu umum dilakukan sebanyak satu kali dalam satu bulan dengan kunjungan petugas gizi berkala pada saat jadwal posyandu dilakukan.

\section{Pengetahuan Gizi Ibu Balita}

Dari 22 ibu yang hadir pada saat edukasi gizi, hanya 19 responden yang dapat di analisis. Tiga lainnya tidak menyelesaikan posttest karena sudah meninggalkan lokasi penelitian pada saat pengisian kuesioner posttest. Response rate penelitian ini sebesar $86,4 \%$. Pada awal sesi sebelum diberikan pendidikan gizi tentang stunting, mayoritas ibu masih memiliki pengetahuan yang cukup $(57,9 \%)$ dan kurang $(36,8 \%)$. Hanya $5,3 \%$ yang memiliki pengetahuan gizi baik (Tabel 1). Pengetahuan gizi pada penelitian ini di nilai menggunakan kuesioner berisi 10pertanyaan tentang stunting, pencegahan stunting, dan manfaat konsumsi ikan untuk mencegah stunting.
Kategori pengetahuan gizi dikelompokkan sebagai baik apabila skor >80; sedang jika skor $60-79$ dan kurang jika skor $<60^{11}$. Tingkat pengetahuan merupakan salah satu faktor yang secara tidak langsung dapat memengaruhi status gizi anak, termasuk stunting dengan terlebih dahulu memengaruhi perilaku ibu. Hasil telaah literatur sebelumnya menunjukkan bahwa salah satu penelitian case control di Mozambique dengan 282 sampel menyimpulkan bahwa intervensi gizi untuk meningkatkan pengetahuan menjadi faktor penentu terjadinya masalah stunting pada anak ${ }^{12}$. Sejalan dengan hal tersebut, Yisak et al $^{13}$ juga berargumen bahwa pendidikan gizi yang diberikan kepada ibu atau pengasuh anak dapat menjadi salah satu alternatif pencegahan stunting.

Tabel 2 menunjukkan hasil mean jawaban pada masing-masing item pertanyaan. Hasil ini akan berguna untuk menggali lebih dalam terkait hal-hal yang kurang diketahui oleh responden sehingga intervensi gizi yang akan dilakukan dapat memfokuskan pada hal-hal yang belum diketahui tersebut. Pertanyaan pertama bertujuan untuk mengobservasi apakah ibu balita mengetahu tentang istilah stunting. saat pretest, rata-rata skor 7,4 sedangkan setelah edukasi gizi, $100 \%$ ibu mengetahui tentang istilah stunting. Hasil tersebut juga meningkat secara signifikan $(p<0,05)$. Istilah stunting didefinisikan sebagai kondisi dimana anak balita memiliki panjang badan $(\mathrm{PB} / \mathrm{U})$ atau tinggi badan $(\mathrm{TB} / \mathrm{U})$ menurut umurnya kurang dibandingkan dengan standar baku WHO-MGRS (3). Saat ini, istilah stunting juga banyak digunakan dalam berbagai media kampanye kesehatan anak baik di Posyandu, Puskesmas, dan Rumah Sakit sehingga membuat mayoritas ibu balita sudah mengetahui istilat tersebut. Indonesia sendiri saat ini menjadi satu dari 60 negara yang berkomitmen untuk menurunkan angka stunting melalui gerakan 1000 Hari Pertama Kehidupan (HPK) atau Scaling Up Nutrition (SUN) yang dijalankan sejak tahun $2010^{14}$.

Tabel 1. Pengetahuan Gizi Ibu Balita Sebelum dan Sesudah Edukasi Gizi

\begin{tabular}{lcccc}
\hline \multirow{2}{*}{ Pengetahuan Gizi } & \multicolumn{2}{c}{ Sebelum (n=19) } & \multicolumn{2}{c}{ Sesudah (n=19) } \\
\cline { 2 - 5 } & $\mathbf{n}$ & $\mathbf{0}$ & $\mathbf{n}$ & $\mathbf{\%}$ \\
\hline Kurang & 7 & 36,8 & 1 & 5,3 \\
Cukup & 11 & 57,9 & 5 & 26,3 \\
Baik & 1 & 5,3 & 13 & 68,4 \\
Jumlah & $\mathbf{1 9}$ & $\mathbf{1 0 0}$ & $\mathbf{1 9}$ & $\mathbf{1 0 0}$ \\
\hline
\end{tabular}

Pertanyaan selanjutnya merujuk pada faktor langsung yang menyebabkan stunting. Rata-rata nilai pretest untuk soal ini hanya 3,7 dan meningkat secara signifikan saat post-test dengan rata-rata $9,5(p<0,05)$. Pengetahuan tentang faktor risiko stunting sangat penting bagi ibu balita agar dapat mengeliminasi faktor tersebut dan mencegah terjadinya stunting. Budiastutik dan Rahfiludin ${ }^{12}$ menjelaskan faktor risiko utama stunting di negara berkembang adalah tidak terpenuhinya gizi yang dibutuhkan dalam jangka waktu yang lama. Selain itu, faktor kesehatan seperti terjadinya infeksi berulang juga menjadi penyebab langsung terjadinya stunting. Studi pada Balita di pedesaan dan perkotaan Jember menunjukkan hasil yang sama dimana faktor terjadinya infeksi berhubungan dengan kejadian stunting ${ }^{15}$. Lebih dalam dijelaskan bahwa terjadinya infeksi pada balita dapat memengaruhi peningkatan kebutuhan akibat peningkatan metabolisme, mengganggu penyerapan zat gizi, penurunan nafsu makan dan asupan makanan, dan kehilangan zat gizi ${ }^{16}$. Infeksi dan stunting memiliki hubungan yang sinergestik. Kemudian pertanyaan ke-4, 5, dan 8 berkaitan dengan praktek pemberian MPASI. Pengetahuan tentang Pemberian Makan Bayi dan Anak (PMBA) dalam hal ini yaitu MPASI penting untuk diketahui oleh ibu karena dapat memengaruhi asupan gizi bayi. Hasil studi ini juga sejalan dengan studi di Kota Cimahi yang menemukan perbedaan bermakna pada rata-rata skor pengetahuan sebelum dan setelah intervensi pendidikan gizi menggunakan booklet PMBA. Selain itu, pendidikan gizi yang diberikan juga berpengaruh pada skor feeding practice. Ibu yang diberikan intervensi gizi meningkat pengetahuan dan feeding practice, artinya bahwa kemampuan ibu dalam memberi makanan menjadi lebih baik setelah mendapat edukasi gizi ${ }^{17}$. 
Penekanan edukasi gizi juga dilakukan pada pemberian MPASI yang tepat sesuai usia karena rerata skor soal ke- 5 sangat rendah $(0,5)$. Izwardi ${ }^{18}$ menjelaskan bahwa MPASI harus memenuhi 6 syarat: frekuensi makan dalam satu hari, jumlah makanan, tekstur yang tepat, jenis seimbang dan bervariasi, pemberian makanan aktif, dan penyiapan yang bersih. Setelah edukasi gizi, rerata skor meningkat menjadi 6,8 yang berarti bahwa mayoritas ibu balita mengetahui pemberian MPASI yang sesuai, yaitu $6-9$ bulan tekstur saring/lumat, makanan lembik/cincang kasar untuk usia $9-12$ bulan dan makanan keluarga untuk $12-24$ bulan $^{19}$.

Tabel 2. Rata-rata Nilai Pre dan Post-Test pada Masing-Masing Item Pertanyaan (Skala $0-100$ )

\begin{tabular}{lccc}
\hline \multicolumn{1}{c}{ Pertanyaan } & \multicolumn{1}{c}{ Rata-rata nilai (mean \pm SD) } & Post-intervensi \\
\cline { 2 - 3 } $\begin{array}{l}\text { 1. Jika ada seorang anak memiliki TB yang } \\
\text { lebih rendah dibandingkan anak lain yang } \\
\text { usianya sama, maka disebut dengan.. }\end{array}$ & $7,4 \pm 4,5$ & $10,0 \pm 0,0$ & 0,021 \\
\hline $\begin{array}{l}\text { 2. Faktor langsung penyebab stunting pada } \\
\text { anak adalah.. }\end{array}$ & $3,7 \pm 4,9$ & 0,000 \\
\hline $\begin{array}{l}\text { 3. } \text { s syarat yang harus dipenuhi dalam } \\
\text { pemberian MPASI adalah.. }\end{array}$ & $7,9 \pm 4,2$ & $0,5 \pm 2,3$ & 0,429 \\
\hline $\begin{array}{l}\text { 4. MPASI mulai diberikan ktika anak berusia.. } \\
\text { 5. MPASI yang tepat untuk diberikan pada } \\
\text { anak usia 9-11 bulan berupa.. }\end{array}$ & $10,0 \pm 0,0$ & $8,9 \pm 3,2$ & 0,163 \\
\hline $\begin{array}{l}\text { 6. Zat gizi pada ikan yang sangat baik untuk } \\
\text { kecerdasan otak anak adalah.. }\end{array}$ & $0,5 \pm 2,3$ & $8,9 \pm 3,2$ & 0,056 \\
\hline $\begin{array}{l}\text { 7. zat gizi pada ikan yang berguna untuk } \\
\text { memacu pertumbuhan anak dan mengganti } \\
\text { sel-sel tubuh yang rusak adalah... }\end{array}$ & $6,8 \pm 4,8$ & $6,8 \pm 4,8$ & 0,331 \\
\hline $\begin{array}{l}\text { 8. Salah satu akibat yang dapat ditimbulkan } \\
\text { jika makanan pendamping ASI diberikan } \\
\text { terlalu awal (kurang dari 6 bulan) adalah.. }\end{array}$ & $9,5 \pm 2,3$ & $9,5 \pm 2,3$ & 0,104 \\
\hline $\begin{array}{l}\text { 9. Berikut adalah salah satu cara yang dapat } \\
\text { dilakukan untuk mencegah stunting yaitu.. }\end{array}$ & $3,4 \pm 4,5$ & $8,4 \pm 3,7$ & 0,000 \\
\hline $\begin{array}{l}\text { 10. Ikan memiliki manfaat jangka panjang } \\
\text { untuk kehidupan anak yaitu.. }\end{array}$ & $3,7 \pm 4,9$ & $9,5 \pm 2,3$ & 0,000 \\
\hline
\end{tabular}

Pertanyaan ke-enam dan tujuh berkaitan dengan kandungan zat gizi pada ikan. Terdapat peningkatan rerata skor pengetahuan pada soal kandungan omega-3 pada ikan, namun ibu balita justru memiliki rerata nilai yang kurang pada pertanyaan ketujuh tentang kandungan protein dalam ikan. Tidak terdapat perbedaan yang signifikan pada kedua pertanyaan sebelum dan sesudah intervensi edukasi gizi. $(p>0,05)$ Ikan merupakan salah satu jenis protein hewani yang penting dalam pencegahan stunting. Kandungan protein dalam ikan mencapai $18 \%$ dan terdiri dari asam amino esensial. Menurut Daftar Bahan Makanan Penukar (DBMP) Indonesia, satu porsi ikan segar (50 g) mengandung 10 gram protein. Asupan protein sangat penting dalam rangka pencegahan stunting. Asupan protein secara positif berkorelasi dengan pertumbuhan linear pada anak setelah di kontrol dengan faktor inflamasi, parasit usus, dan faktor sosio demografi' ${ }^{20}$. Pertanyaan ke-10 juga membahas tentang manfaat jangka panjang konsumsi ikan yaitu untuk pencegahan stunting. Pengetahuan ibu bahwa ikan dapat mencegah stunting meningkat secara signifikan sebelum dan sesudah intervensi pendidikan gizi $(p<0,05)$. Pemerintah Indonesia melalui Kementerian Kelautan dan Perikanan (KKP) menggalakkan program "Gemarikan" sebagai salah satu upaya peningkatan konsumsi ikan dan diperkuat oleh Keputusan Gubernur Jawa Timur Nomor 188/319/KPTS/013/2010 tentang Forum Peningkatan Konsumsi Ikan (FORIKAN) Provinsi Jawa Timur ${ }^{21}$. Edukasi gizi yang dilakukan dalam penelitian ini telah mendukung program pemerintah dan secara tidak langsung dapat membantu pencegahan stunting.

Tabel 3. Pengaruh Edukasi Gizi Terhadap Pengetahuan Gizi Siswa

\begin{tabular}{ccccc}
\multirow{2}{*}{ Variabel } & \multirow{2}{*}{ N } & \multicolumn{2}{c}{ Rata-rata \pm SD } & \multirow{2}{*}{$\boldsymbol{P}$} \\
\cline { 2 - 3 } Pengetahuan Gizi & 19 & $60,5 \pm 18,9$ & $88,4 \pm 13,8$ & 0,002 \\
\hline
\end{tabular}

Gambar 1 menunjukkan adanya tren peningkatan skor pengetahuan gizi sebelum dan sesudah dilakukannya intervensi edukasi gizi pada ibu balita. Penelitian ini menunjukkan bahwa pemberian edukasi gizi dengan metode penyuluhan konvensional dan tanya jawab dapat meningkatkan skor pengetahuan ibu balita secara signifikan ( $p$-value $=0,002$ ). Rerata skor sebelum edukasi sebesar $60,5 \pm 18,9$ dan meningkat menjadi 88,4 $\pm 13,8$ setelah edukasi gizi. Hasil ini juga sejalan dengan penelitian Andriani, et al ${ }^{22}$ di wilayah kerja Puskesas Puuwatu, Kota Kendari yang menunjukkan adanya peningkatan pengetahuan yang bermakna setelah 
pemberian edukasi gizi berbasis MSG $(\mathrm{p}=0,000)$. MSG atau MOTHER SMART GROUNDING merupakan program paket edukasi gizi berupa penyuluhan konvensional, pembagian booklet, dan demontrasi jajanan sehat berbahan pangan lokal kelor (Moringa oleifera) yang bertujuan untuk mencegeah stunting. Hasil penelitian yang pertama kali dilakukan di Desa GempolManis, kecamatan Sambeng, kabupaten Lamongan ini dapat menjadi bahan advokasi kepada pemerintah setempat untuk membuat program edukasi gizi menjadi program preventif utama pencegaha stunting karena terbukti dapat meningkatkan pengetahuan ibu balita. Akan tetapi, beberapa kelemahan penelitian ini perlu diperbaiki kedepannya seperti jumlah sampel yang dapat ditambah dengan desa lain dalam satu kecamatan agar memperoleh jumlah yang lebih besar serta monitoring pengetahuan ibu setelah jangka waktu tertentu untuk memastikan apakah hasil edukasi masih dirasakan. Selain itu, pengembangan kuesioner juga perlu dilakukan agar dapat mencakup pengetahuan gizi secara komprehensif.

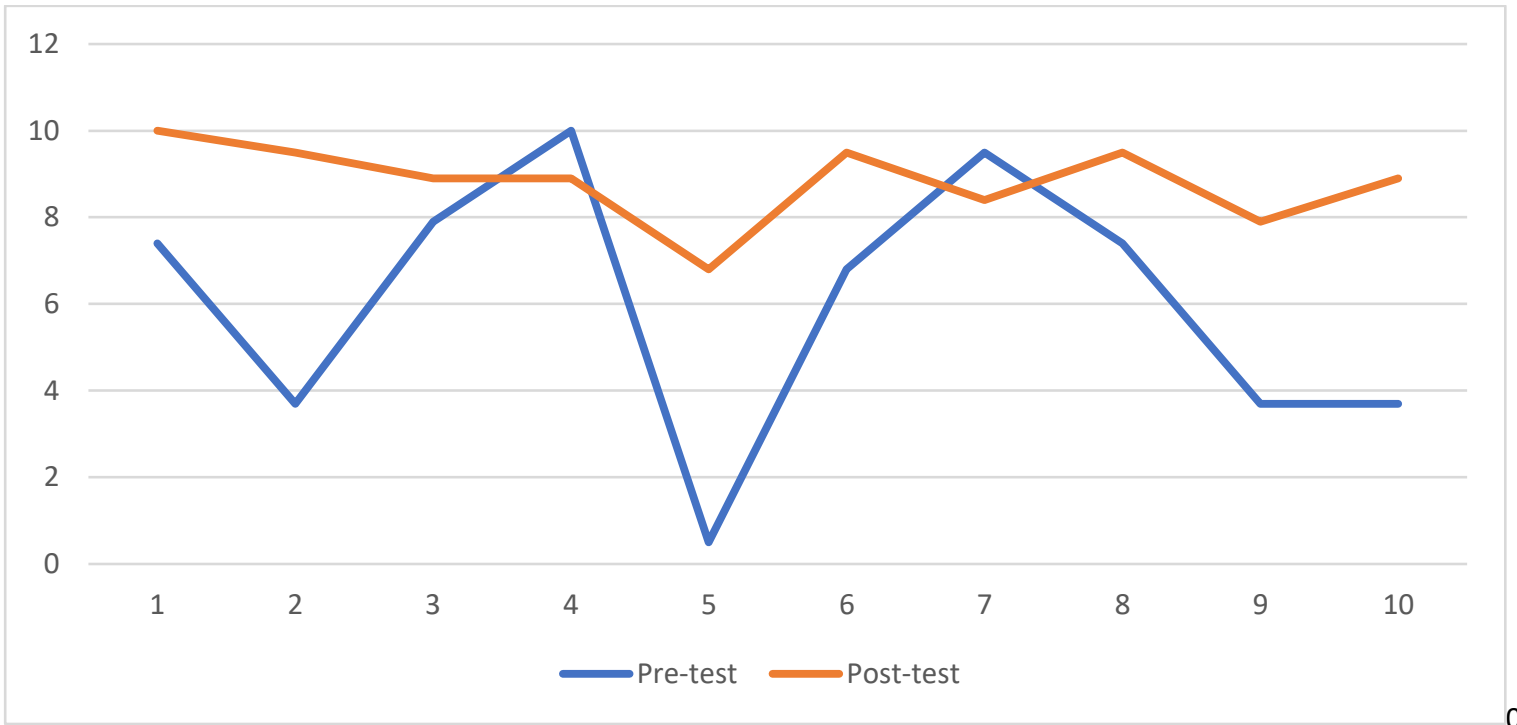

Gambar 1. Grafik Nilai Pretest dan Posttest Pengetahuan Ibu

\section{KESIMPULAN}

Penelitian ini menunjukkan bahwa pendidikan gizi secara signifikan dapat meningkatkan pengetahuan ibu terkait pencegahan stunting pada anak di usia emas golden period. Pemberian edukasi gizi secara berkala baik oleh petugas gizi puskesmas maupun kader posyandu perlu dilakukan sebagai upaya pencegahan stunting.

\section{ACKNOWLEDGEMENT}

Penulis mengucapkan terimakasih kepada masyarakat dan perangkat Desa Gempolmanis Kecamatan Sambeng, Kapubaten Lamongan khususnya Ibu Puji Selaku Sekretaris Desa yang banyak membantu kelancaran kegiatan ini. Terima kasih pada mahasiswa UNAIR yang membantu dalam pengumpulan data dan teman dosen atas masukan, pendapat maupun saran dalam perancangan dan penyelesaian penulisan artikel ini. Terima kasih setingginya kami ucapkan pada Direktorat Riset dan Pengabdian Masyarakat, Deputi Bidang Penguatan Riset dan Pengembangan Kementerian Riset dan Teknologi/ Badan Riset dan Inovasi Nasional yang telah memberikan bantuan pendanaan sehingga penelitian ini dapat dijalankan.

\section{REFERENS}

1. Unicef. Gizi Ibu \& Anak. Unicef Indones. 2012;1-6.

2. Sjarif DR, Yulianti K, Lestari ED, Sidiartha IGL, Nasar SS, Mexitalia M. Rekomendasi Praktik Pemberian Makan Berbasis Bukti pada Bayi dan Batita di Indonesa untuk Mencegah Malnutrisi. 1st ed.
Jakarta: UKK Nutrisi dan Penyakit Petabolik Ikatan Dokter Anak Indonesia; 2015.

3. TNP2K. 100 Kabupaten/ Kota Prioritas Untuk Intervensi Anak Kerdil (Stunting). 1st ed. Jakarta: Tim Nasional Percepatan Penanggulangan Kemiskinan; 2017.

4. KEMENKES. RISET KESEHATAN DASAR tahun 2013. Jakarta: Badan Penelitian dan Pengembangan Kesehtan Kementerian Kesehatan RI Tahun 2013; 2013.

5. Kemiskinan, Tim Nasional Percepatan Penanggulangan. "100 kabupaten/kota prioritas untuk intervensi anak kerdil (stunting)." Jakarta: Tim Nasional Percepatan Penanggulangan Kemiskinan(2017).

6. Adani FY, Nindya TS. Perbedaan Asupan Energi, Protein, Zink, dan Perkembangan pada Balita Stunting dan non Stunting. Amerta Nutrition. 2017 Oct 23;1(2):46-51.

7. Diabetes, RSCM Pusat, and Lipid Jakarta. "Daftar Bahan Makanan Penukar." Ja ka rta (2010).

8. Balitbangkes. Laporan Studi Diet Total 2014. 2015. Jakara: Balitbangkes Kemenkes RI

9. Ditjen PDSPKP (Direktorat Jenderal Penguatan Daya Saing Produk Kelautan dan Perikanan Kementerian Kelautan dan Perikanan). Konsumsi Ikan 2010 2015.

10. Depkes RI. Ikan untuk ketahanan pangan dan gizi. 2015. Diakses di http://gizi.depkes.go.id/ pada 3 Februari 2017. 
11. Khomsan, Ali., Faisal Anwar1 dan Eddy S. Mudjajanto. Pengetahuan, Sikap, Dan Praktek Gizi Ibu Peserta Posyandu. Jurnal Gizi dan Pangan, Maret 2009 4(1): $33-41$

12. Budiastutik dan Rahfiludin. Faktor Risiko Stunting pada anak di Negara Berkembang. Amerta Nutr (2019) 122-126

13. Yisak, H., Gobena, T. \& Mesfin, F. Prevalence and risk factors for under nutrition among children under five at Haramaya district, Eastern Ethiopia. BMC Pediatr. 1-7 (2015). doi:10.1186/s12887-0150535-0

14. WHO. Leveraging diverse stakeholders to tackle all forms of malnutrition: Lessons from the SUN Movement. November, 2019. Available at https://www.who.int/nutrition/events/2018-fpghworkshop-nutrition-against-ncd-16novpresentation-EdwynShiell-SUN.pdf?ua $=1$

15. Aridiyah, FO., Ninna Rohmawati., Mury Ririanty. Faktor-faktor yang Mempengaruhi Kejadian Stunting pada Anak Balita di Wilayah Pedesaan dan Perkotaan. e-Jurnal Pustaka Kesehatan, vol. 3 (no. 1) Januari 2015.

16. Suiraoka I, Kusumajaya A dan Larasati N. Perbedaan Konsumsi Energi, Protein, Vitamin A dan Frekuensi Sakit Karena Infeksi Pada Anak Balita Status Gizi Pendek (Stunted) dan Normal di Wilayah Kerja Puskesmas Karangasem I. JIG. Februari 2011: Vol (2): 74-82. Available from: http://poltekkesdenpasar.ac.id/

17. Dewi, Maryati., Mimin Amina. Pengaruh Edukasi Gizi terhadap Feeding Practice Ibu Balita Stunting Usia 6-24 Bulan. Indonesian Journal of Human Nutrition, Juni 2016, Vol.3 No.1 Suplemen : 1 - 8

18. Izwardy, Doddy. Praktik Pemberian Makanan Bayi dan Anak (PMBA) Untuk Perubahan Perilaku
Pemenuhan Asupan Gizi Anak Dalam Upaya Pencegahan Stunting. November, 2018. Diakses melalui

http://www.kesmas.kemkes.go.id/assets/upload/d ir 60248a365b4ce1e/files/1PAPARAN-STUNTINGDIR.GIZI 1222.pdf

19. Kementrian Kesehatan. Makanan Sehat untuk Bayo. 2013. Diakses pada depkes.go.id

20. Tessema, Masresha., Nilupa S. Gunaratna, Inge D. Brouwer, et al. Associations among High-Quality Protein and Energy Intake, Serum Transthyretin, Serum Amino Acids and Linear Growth of Children in Ethiopia. Nutrients 2018, 10, 1776; doi:10.3390/nu10111776

21. Keputusan Gubernur Jawa Timur Nomor 188/319/KPTS/013/2010 tentang Forum Peningkatan Konsumsi Ikan (FORIKAN) Provinsi Jawa Timur

22. Andriani, Wa Ode Sri., Farit Rezal., WD. ST. Nurzalmariah. Perbedaan Pengetahuan, Sikap, Dan Motivasi Ibu Sesudah Diberikan Program Mother Smart Grounding (MSG) Dalam Pencegahan Stunting Di Wilayah Kerja Puskesmas Puuwatu Kota Kendari Tahun 2017. Jurnal Ilmiah Mahasiswa Kesehatan Masyarakat, VOL. 2/NO.6/ MEI 2017; ISSN 250-731X

23. Izawrdy, Doddy. Kebijakan dan Strategi Penanggulangan Stunting di Indonesia. Disampaikan dalam FGD Skrining Malnutrisi pada Anak di Rumah Sakit. Jakarta, 2019.

24. Rachim AN, Pratiwi R. Hubungan Konsumsi Ikan Terhadap Kejadian Stunting Pada Anak Usia 2-5 Tahun. Jurnal Kedokteran Diponegoro. 2017;6(1):36-45. 